\title{
ANALISIS KELAYAKAN FINANSIAL BUDIDAYA SELADA DENGAN HIDROPONIK SEDERHANA SKALA RUMAH TANGGA
}

\author{
Dian Novitasari $^{1^{*}}$, Risqa Naila Khusna Syarifah ${ }^{2}$ \\ ${ }^{1}$ Jurusan Teknologi Pertanian, Fakultas Pertanian, Universitas Jenderal Soedirman \\ Jl. Dr. Soeparno, Karangwangkal, Purwokerto 53122 \\ ${ }^{2}$ Jurusan Agroteknologi, Fakultas Pertanian, Universitas Jenderal Soedirman \\ Jl. Dr. Soeparno, Karangwangkal, Purwokerto 53122 \\ "Corresponding author: diannov.tep@unsoed.ac.id
}

\begin{abstract}
Lettuce is one of the most popular leaf vegetables that has a high economic value. Lettuce can be the potential leaf vegetables to be cultivated hydroponically and can be used as a source of additional income for the family. Therefore, the feasibility study of hydroponic lettuce cultivation of the household scale is needed. This study aims to know the feasibility of hydroponic lettuce cultivation of household scale by using Net Present Value (NPV), the value of Payback Periode (PP), and the $B / C$ ratio. This research was conducted in Grendeng village, North Purwokerto sub-district, Banyumas district from September until December 2019. The results showed that the $N P V$ was $R p$. 24,130,112.00; the value of the B/C ratio was 3.51; and PP value was 2 months 28 days, so it can be concluded that the business is feasible to be implemented.
\end{abstract}

Keywods: feasibility study, hydroponic, household scale, lettuce

\begin{abstract}
Abstrak: Selada merupakan salah satu sayuran daun yang banyak diminati dengan nilai ekonomis yang tinggi. Hal tersebut membuat selada menjadi salah satu sayuran daun yang potensial untuk dibudayakan secara hidroponik dan dapat digunakan sebagai sumber pendapatan tambahan bagi keluarga. Oleh sebab itu dibutuhkan kajian mengenai kelayakan usaha budidaya selada secara hidroponik dalam skala rumah tangga. Penelitian ini bertujuan untuk mengetahui kelayakan usaha budidaya selada secara hidroponik dalam skala rumah tangga dengan menggunakan Net Present Value (NPV), nilai Payback Periode (PP), serta B/C ratio. Penelitian ini telah dilaksanakan di kelurahan Grendeng, kecamatan Purwokerto Utara, kabupaten Banyumas pada bulan September hingga Desember 2019. Hasil penelitian menunjukkan bahwa NPV yang didapatkan sebesar Rp. 24.130.112,00; nilai B/C rasio sebesar 3,51; serta PP sebesar 2 bulan 28 hari, sehingga dapat disimpulkan bahwa usaha tersebut layak untuk dilaksanakan.
\end{abstract}

Kata kunci: hidroponik, kelayakan usaha, selada, skala rumah tangga

\section{PENDAHULUAN}

Sayur merupakan unsur penting bagi kesehatan mengingat tingginya kandungan vitamin dan mineral di dalamnya. Hal tersebutlah yang melatarbelakangi banyaknya masyarakat yang mengkonsumsi sayur, sehingga tingkat konsumsi sayur di Indonesia menjadi tinggi. Hal tersebut dapat dilihat dari data BPS (2017) jumlah pendenduduk Indonesia yang mengkonsumsi sayur sebesar $97,29 \%$ dari total keseluruhan penduduk. Besarnya tingkat konsumsi tersebut akan berdampak pada peningkatan kebutuhan sayuran. Kebutuhan akan sayuran tersebut akan terus meningkat berbanding lurus dengan pertambahan jumlah penduduk.

Salah satu sayuran yang mengalmi peningkatan permintaan karena banyak diminati oleh masyarakat adalah selada. Selada merupakan sayuran yang dapat digunakan sebagai pelengkap bebagai hidangan serta 
bahan tambahan makanan siap saji. Selain itu selada memiliki banyak kandungan gizi dan vitamin seperti fosfor, kalsium, vitamin A, B, dan C, serta zat besi (Setyaningrum dan Saparinto, 2011). Hal inilah yang membuat selada banyak diminati oleh masyarakat mulai dari ibu rumah tangga, pedagang makanan siap saji, warung makan, hotel, maupun usaha kuliner lainnya.

Tingginya permintaan selada mengakibatkan Indonesia harus melakukan import untuk memenuhi kebutuhan selada dalam negeri. Jumlah import selada di Indonesia pada tahun 2015 sebesar $238.461 \mathrm{~kg}$ (BPS, 2016). Import selada terjadi sebagai akibat dari tingginya permintaan selada yang tidak diikuti dengan peningkatan produksi selada. Produksi selada rendah tersebut diakibatkan oleh penyempitan lahan pertanian karena perluasan lahan untuk pemukiman maupun untuk pendirian usaha diluar usaha budidaya. Permasalahan tersebut jika tidak diatasi dapat mengakibatkan kurangnya pasokan selada dari dalam negeri sehingga akan mengakibatkan tingginya tingkat import selada untuk memenuhi kebutuhan pangan.

Dibutuhkan solusi budidaya yang efektif dengan memanfaatkan lahan yang sempit untuk menyelesaikan permasalahan tersebut mengingat prospek bisnis budidaya selada yang cukup menjanjikan karena banyaknya permintaan pasar, hal ini dapat dilihat tingginya angka import pada tahun 2015. Selain itu selada juga merupakan sayuran yang memiliki nilai ekonomis dibandingkan dengan sayuran daun lainnya, dimana harga jual selada di pasaran dapat mencapai Rp. $28.000,00$ perkilo (Conainthata G, 2020).

Berdasarkan permasalahan tersebut maka dibutuhkan suatu solusi yang dapat dilakukan untuk merubah pola pertanian yang awalnya berbasis tanah (konvensional), yaitu dengan cara menerapkan pola pertanian berbasis air (hidroponik). Hidroponik merupakan alternatif teknologi budidaya untuk masyarakat yang memiliki lahan ataupun pekarangan yang terbatas, sehingga dapat digunakan sebagai sumber penghasilan tambahan bagi masingmasing rumah tangga (Roidah, 2014). Pemilihan alternatif tersebut tersebut dikarenakan penggunaan air dan tanah dalam budidaya secara hidroponik lebih efisien jika dibandingkan dengan pertanian konvensional, sehingga dapat dikatakan bahwa budidaya hidroponik dapat menghemat biaya produksi dan kualitas yang dihasilkan baik (Barbosa et al., 2015; Siswoyo dan Sari, 2018; Wahyu, 2018; Pratiwi et al., 2019).

Berdasarkan pernyataan di atas, maka perlu dilakukan kajian mengenai kelayakan usaha budidaya selada secara hidroponik sederhana untuk mengetahui besarnya pengeluaran dan pendapatan dari budidaya selada secara hidroponik skala rumah tangga dengan pemanfaatan pekarangan. Analisis tersebut diharapkan dapat memberikan gambaran usaha budidaya hidroponik skala rumah tangga dan memberikan gambaran peluang bisnis yang cukup menguntungkan.

\section{METODE PENELITIAN}

Penelitian dilakukan di Kelurahan Grendeng, Kecamatan Purwokerto Utara, Kabupaten Banyumas. Penelitian dilaksanakan selama 3 bulan dari bulan September-Desember 2019. Penelitian ini menggunakan data primer yang bersifat kuantitatif. Data tersebut berupa data biaya yang dikeluarkan dan didapatkan saat melakukan budidaya selada dengan metode hidroponik serta data hasil panen. Pengambilan data dilakukan dengan melihat besarnya biaya investasi, biaya tetap, dan biaya variabel yang digunakan dalam proses budidaya, serta penerimaan usaha.

Analisis data yang dilakukan meliputi:

1. Analisis NPV

NPV merupakan selisih dari hasil perhitungan manfaat serta biaya pada kondisi sekarang selama bisnis dijalankan yang dihitung menggunakan rumus berikut (Nurmalina R et al., 2014):

$\mathrm{NPV}=\sum_{t=0}^{n} \frac{B_{t}-C_{t}}{(1+i)^{t}}$

Keterangan:

$\mathrm{Bt}=$ Manfaat pada tahun ke- $\mathrm{t}$

$\mathrm{Ct}=$ Biaya $($ cost $)$ pada tahun ke- $\mathrm{t}$

$\mathrm{n}=$ Umur proyek

$\mathrm{i}=$ Tingkat discount rate (\%)

$\mathrm{t}=$ tahun kegiatan bisnis

Hasil perhitungan NPV tersebut memiliki 3 kriteria untuk menentukan kelayakan 
usaha, yaitu: (1) layak (NPV > 0), (2) sulit $(\mathrm{NPV}=0)$, dan (3) tidak layak (NPV < 0).

2. Analisis B/C Ratio

Nilai $B / C$ ratio adalah hasil perhitungan yang membandingkan antara manfaat serta biaya selama bisnis dijalankan yang dihitung menggunakan rumus berikut (Nurmalina et al. 2014):

Net B/C $=\frac{\sum_{t=1}^{n} \frac{B_{t}-C_{t}}{(1+i)^{t}}>0}{\sum_{t=1}^{n} \frac{B_{t}-C_{t}}{(1+i)^{t}}<0}$

Keterangan:

$\mathrm{Bt}=$ Manfaat (benefit) tahun ke- $\mathrm{t}$

$\mathrm{Ct}=$ Biaya $($ cost $)$ tahun ke- $\mathrm{t}$

$\mathrm{t}=$ Tahun

$\mathrm{i}=$ Discount rate $(\%)$

Hasil perhitungan $\mathrm{B} / \mathrm{C}$ ratio akan menggambarkan kelayakan usaha untuk dijalankan jika nilai $\mathrm{B} / \mathrm{C}$ ratio $>1$.

3. Analisis PP

PP merupakan hasil perhitungan terhadap jangka waktu untuk mengetahui periode waktu pengembalian investasi yang dihitung dengan rumus berikut (Nurmalina et al. 2014):

$\mathrm{PP}=\frac{I}{A b}$

Keterangan:

PP = Jumlah waktu (tahun) yang diperlukan untuk mengembalikan modal yangditanamkan

$\mathrm{I}=$ Besarnya biaya investasi yang diperlukan

$\mathrm{Ab}=$ Manfaat bersih yang dapat diperoleh pada setiap tahunnya

Menurut Sutrisno (2009), terdapat dua kriteria investasi untuk menentukan kelayakan usaha, yaitu: (1) layak (PP < umur usaha) dan (2) tidak layak (PP > umur usaha).

\section{HASIL DAN PEMBAHASAN}

\section{Proyeksi Arus Kas (Cash Flow)}

Proyeksi cash flow ini menggambarkan aliran arus kas masuk (inflow) serta arus kas keluar (outflow) selama usaha dijalankan.
1. Arus Kas Masuk

Arus kas masuk merupakan segala penerimaan yang diperoleh selama berjalannya usaha. Arus kas masuk pada usaha budidaya selada hidroponik siperoleh dari nilai penjualan yang dihitung dari perkiraan jumlah produksi yang dikalikan dengan harga jual selada. Harga jual selada sekitar Rp. 25.000,00/kg dan jumlah produksi rata-rata selama satu tahun sebesar $480 \mathrm{~kg}$, sehingga total arusa kas masuk selama 1 tahun sebesar Rp. 12.000.000,00. Adapun arus kas masuk dapat dilihat pada Tabel 1.

Tabel 1. Penerimaan Usaha Budidaya Hidroponik Selada Skala Rumah Tangga

\begin{tabular}{|c|c|c|c|}
\hline Produk & $\begin{array}{l}\text { Hasil } \\
\text { panen } \\
(\mathrm{kg})\end{array}$ & $\begin{array}{c}\text { Penerimaan } \\
(\mathrm{Rp} / \mathrm{kg})\end{array}$ & $\begin{array}{c}\text { Penerimaan } \\
\text { (Rp/tahun) }\end{array}$ \\
\hline Selada & 480 & 25.000 & 12.000 .000 \\
\hline \multicolumn{3}{|c|}{ Jumlah } & 12.000 .000 \\
\hline
\end{tabular}

2. Arus Kas Keluar

Arus kas keluar menjelaskan biaya yang keluar selama menjalankan suatu usaha, yang terdiri dari biaya investasi dan biaya operasional. Biaya investasi merupakan besarnya biaya yang digunakan oleh pemilik usaha pada saat awal melakukan usaha. Besarnya biaya tersebut dapat dilihat pada Tabel 2.

Tabel 2. Biaya Investasi Budidaya Hidroponik Selada Skala Rumah Tangga

\begin{tabular}{clcr}
\hline No & Investasi & Kuantitas & \multicolumn{1}{c}{ Biaya (Rp) } \\
\hline 1 & Bor listrik & 1 buah & 300.000 \\
2 & Rak Bambu & 1 buah & 1.000 .000 \\
3 & Ember & 50 buah & 250.000 \\
& (tempat & & \\
& tanam) & 200 buah & 100.000 \\
4 & Net Pot & 10 buah & 200.000 \\
5 & Nampan & 2 buah & 100.000 \\
6 & Ember & 1 buah & 50.000 \\
7 & Gelas Ukur & 2.000 .000 \\
\hline \multicolumn{3}{c}{ Total } \\
\hline \multicolumn{4}{c}{} \\
\hline
\end{tabular}

Biaya operasional terdiri dari biaya tetap dan biaya variabel. Biaya tetap merupakan yang dikeluarkan untuk operasional usaha yang tidak dipengaruhi oleh jumlah tidak habis dalam satu masa produksi. Besarnya biaya tersebut dapat dilihat pada Tabel 3 . 
Tabel 3. Biaya Tetap Budidaya Hidroponik Selada Skala Rumah Tangga

\begin{tabular}{|c|c|c|c|}
\hline No & $\begin{array}{c}\text { Jenis } \\
\text { Pengeluaran }\end{array}$ & Kuantitas & Biaya (Rp) \\
\hline 1 & Transportasi & 48 kali & 1.500 .000 \\
\hline & Total & & 1.500 .000 \\
\hline
\end{tabular}

Biaya variabel adalah biaya yang besarnya dipengaruhi dengan jumlah produksi. Adapun biaya variabel yang dikeluarkan selama satu tahun budidaya selada hidroponik dapat dilihat pada Tabel 4.

Tabel 4. Biaya Variabel Budidaya Hidroponik Selada Skala Rumah Tangga

\begin{tabular}{|c|c|c|c|}
\hline No & $\begin{array}{c}\text { Jenis } \\
\text { Pengeluaran } \\
\end{array}$ & Kuantitas & Biaya (Rp) \\
\hline 1 & Benih & 6 Bungkus & 90.000 \\
\hline 2 & Nutrisi & 48 Bungkus & 768.000 \\
\hline 3 & Air & 500 liter & 150.000 \\
\hline 4 & Rock Woll & 8 buah & 120.000 \\
\hline 5 & Kain Flanel & 8 buah & 120.000 \\
\hline \multicolumn{3}{|c|}{ Total } & 1.248 .000 \\
\hline
\end{tabular}

Sehingga total biaya tetap yang dikeluarkan setiap tahun adalah penjumlahan dari total biaya tetap dan biaya variabel. Berdasarkan data yang didapat, maka total biaya per tahun yang harus dikeluarkan adalah $\mathrm{Rp}$. 2.748.000,00.

\section{Analisis Kelayakan Finansial}

Analisis kelayakan finansial untuk melihat keadaan selama 3 tahun menjalankan usaha budidaya selada secara hidroponik skala rumah tangga. Adapun hasil perhitungannya sebagai berikut:

1. Net Present Value (NPV)

Hasil perhitungan NPV dapat dilihat pada Tabel 5 yang dihasilkan dari perhitungan selama tiga tahun menjalankan usaha dengan tingkat suku bunga sebesar 3,08\% yang diperoleh dari rata-rata nilai inflasi satu tahun.

Tabel 5. NPV Usaha Budidaya Hidroponik Selada Skala Rumah Tangga

\begin{tabular}{ccccc}
\hline $\begin{array}{c}\text { Tahun } \\
\text { ke- }\end{array}$ & $\begin{array}{c}\text { Penerimaan } \\
(\mathrm{Bt})\end{array}$ & Biaya $(\mathrm{Ct})$ & Nilai & NPV \\
\hline 0 & - & 2.000 .000 & $(2.000 .000)$ & $(2.000 .000)$ \\
1 & 12.000 .000 & 2.748 .000 & 9.252 .000 & 8.975 .553 \\
2 & 12.000 .000 & 2.748 .000 & 9.252 .000 & 8.707 .366 \\
3 & 12.000 .000 & 2.748 .000 & 9.252 .000 & 8.447 .193 \\
\hline \multicolumn{5}{l}{ Nilai NPV Proyek } \\
\hline
\end{tabular}

\section{Payback Period (PP)}

Adapun hasil perhitungan PP dari usaha ini ditunjukkan pada Tabel 6 .

Tabel 6. PP Usaha Budidaya Hidroponik Selada Skala Rumah Tangga

\begin{tabular}{crr}
\hline $\begin{array}{c}\text { Tahun } \\
\text { Ke- }\end{array}$ & Laba/Rugi & $\begin{array}{r}\text { Pengaruh Terhadap } \\
\text { Investasi Awal }\end{array}$ \\
\hline 0 & $(2.000 .000)$ & $(2.000 .000)$ \\
1 & 8.975 .553 & 6.975 .553 \\
2 & 8.707 .366 & 15.682 .919 \\
3 & 8.447 .193 & 24.130 .112 \\
\hline
\end{tabular}

Tabel 6 merupakan gambaran laba/rugi dan pengaruhnya terhadap investasi awal, sehingga dari tabel tersebut dapat dihitung nilai PP dari usaha budidaya hidroponik selada skala rumah tangga adalah 2 bulan 28 hari. Nilai tersebut menggambarkan bahwa modal yang diinvestasikan oleh pemilik usaha akan kembali setelah 2 bulan 28 hari usaha tersebut dijalankan.

3. $\mathrm{B} / \mathrm{C}$ Ratio

Tabel 7 berikut menggambarkan perhitungan nilai $\mathrm{B} /$ Cratio dari usaha yang dijalankan.

Tabel 7. Nilai B/C Ratio Usaha Budidaya Hidroponik Selada Skala Rumah Tangga

\begin{tabular}{cc}
\hline Keterangan & Nilai \\
\hline Benefit & 10.244 .000 \\
Cost & 36.000 .000 \\
B/C & 3,51 \\
\hline
\end{tabular}

Tabel 7 memperlihatkan nilai $\mathrm{B} / \mathrm{C}$ ratio usaha sebesar 3,51, maka usaha tersebut layak untuk dijalankan.

\section{KESIMPULAN}

Usaha ini layak dijalankan danmenghasilkan NPV sebesar Rp. 24.130.112,00 dengan nilai $\mathrm{B} / \mathrm{C}$ ratio sebesar 3,51 dan modal usaha akan kembali setelah 2 bulan 28 hari menjalankan usaha. Berdasarkan hasil penelitian ini, maka perlu dilakukan penelitian terkait budidaya hidroponik sederhana skala rumah tanga untuk jenis sayuran lain untuk diversifikasi usaha dan meningkatkan pendapatan. 


\section{DAFTAR PUSTAKA}

Barbosa, G. L., Gadelha, F. D. A., Natalya Kublik, N., Proctor, A, Reichelm, L., Emily Weissinger, E., Gregory M. Wohlleb, G.M., dan Halden, R. U. 2015. Comparison of Land, Water, and Energy Requirements of Lettuce Grown Using Hydroponic vs. Conventional Agricultural Methods. Int. J. Environ. Res. Public Health, 12(6), 6879-6891.

BPS. 2016. Indikator Pertanian 2015/2016. Jakarta: BPS.

BPS. 2017. Konsumsi Buah dan Sayur Susenas Maret 2016. Jakarta: BPS.

Conainthata, G. (2020/6/1). Update Harga Selada per Kg di pasaran (online). Retrieved from https://harga.web.id/harg a-selada-per-kg-di-pasaran.info.

Nurmalina, R., Sarianti, T., dan Karyadi, A. 2014. Studi Kelayakan Bisnis. Bogor: IPB Press.

Pratiwi, P.Y., Mardiyaningsih, A., dan Widarti, E. 2019. Perbedaan Kualitas Tanaman
Mint (Metha spicata L) Hidroponik dan Konvensional berdasarkan Morfologi Tanaman, Profil Kromatogram, dan Kadar Minyak Atsiri. Jurnal Riset Kefarmasian Indonesia, 1(2), 148-156.

Roidah, I. 2014. Pemanfaatan Lahan dengan Menggunakan Sistem Hidroponik. Jurnal Universitas Tulungagung Bonorowo, 1(2), 43-49.

Setyaningrum, H.D., dan Saparinto, C. 2011. Panen Sayur Secara Rutin di Lahan Sempit. Jakarta: Penebar Swadaya.

Siswoyo, N. A. S. dan Sari, S. 2018. Pengaruh Metode Penananman Hidroponik dan Konvensional terhadap Pertumbuhan Tanaman Bayam Merah. Jurnal Ilmiah Agribisnis. Jurnal Ilmiah Agribisnis, 16(2), 49-54.

Sutrisno. 2009. Manajemen keuangan Teori, Konsep dan Aplikasi. Yogyakarta: Ekonisia.

Wahyu, H. 2018. Analisis Kelayakan Usaha Kangkung Hidroponik di Specta Farm Kabupaten Bogor (Skripsi). Bogor: IPB. 